\title{
ELOGIO DE LA
}

INTRANSIGENCIA

Joaquín Díez-Canedo*

En la primera imagen suya que guardo, Julián Meza está parado al lado de Edén Ferrer, en la banqueta de Insurgentes, a la altura del restaurante Arroyo. Allí había quedado yo de recoger a Edén para acudir a una comida a la que nos había invitado Paco Rebolledo en su casa de Jiutepec. Me parece recordar que Edén no me había anunciado que vendría con él otra persona, así que Julián fue recibido en el coche-lo que hoy se llamaría un "subcompacto"- con una frialdad apenas disimulada, porque iba yo con mi esposa y mis dos hijos; sumen ustedes. No puede haber sido después de 1992, porque en el jardín de los Rebolledo, Joaquín se metió en cueros a una piscinita inflable, lo que no habría hecho si hubiera tenido más de tres años. Los otros convocados fueron el cineasta Raúl Busteros y su mujer, Elena; ellos hicieron el trayecto en la moto de Busteros. Busteros es también gran cocinero, y la paella, que era el menú prometido por Rebolledo, una de sus especialidades. (Si en esta época de inflación gastronómica parece este un comentario anodino es que no se ha tenido la fortuna de probar la paella de Busteros; Paco, por cierto, resultaría buen aprendiz.) Hasta aquí la paella, que fue acompañada de unas botellas seguramente de Rioja (porque debo haberlas aportado yo y entonces era más ortodoxo) y de una no menos opípara charla alrededor de lo que los comensales compartíamos: el mundo literario; chismes, sí,

* Director del Fondo de Cultura Económica. 
pero más bien autores y libros. Dicho más sucintamente: fue una comida memorable, entre otras cosas, claro, porque fue el comienzo de la amistad entre Julián Meza y el que firma estas líneas.

Este comienzo daría pie a una teoría de que la amistad, como los patos, se impronta con lo primero que ve al salir del cascarón. El hecho es que Julián y yo no podemos vernos si no es alrededor de una mesa con alimentos y bebidas, y nuestra charla es una puesta al día de aquella fundacional: repasamos autores y libros, comentamos las noticias de nuestros ámbitos respectivos, y echamos de menos al gran Edén (el gran bricoleur, lo llamó Verónica Volkow en La noche viuda), quien finalmente se salió con la suya y nos dejó solos en este mundo. (Tendrán un atisbo del peculiar genio literario de Ferrer quienes lean un volumen preparado por Julián con poemas, ensayos y su novela Epiclesis, que el Fondo de Cultura Económica publicará pronto.) Lo único que sí procuramos Julián y yo es comer en el D.F.

Mi amistad con Julián transcurre actualmente como al comienzo: alejada de su vida académica, contrariamente a lo que me figuro que sustenta la mayoría de los testimonios aquí publicados. Desde luego, los trabajos y los días de Julián en el ITAM, dedicados nominalmente a la enseñanza de la historia y la literatura-aunque sospecho que en realidad su propósito es sembrar un poco de heterodoxia y dar alguna sazón a las rígidas mentes con vocación para las finanzas, el derecho o la actuaría-, forman también parte del menú de nuestras conversaciones. Además, recibo Estudios tan puntualmente como sale (y suelo leer algunas colaboraciones, no está de más aclararlo). Puedo, por ello, valorar la aportación de Julián a la institución (sus clases me las imagino y me gustaría haber sido su alumno), por la que ahora merecidamente se le reconoce, y me siento autorizado para sumarme a este reconocimiento. Pero en el curriculum de Julián hay que destacar otra versión suya de la vida académica, plasmada en una novela regocijante, El arca de Pandora, cuya primera edición le pedí para Joaquín Mortiz, donde se publicó en 1993. Reseñarla en pocas palabras sería hacerle una injusticia. Consigno, por si fuera de alguna utilidad, mi opinión de que cualquier estudiante con mínimo interés por los libros (lo que lamentablemente no puede 
hoy darse por hecho) se divertirá con su lectura, y que no le hará daño seguirse con las dos novelas históricas (por encajarlas dentro de algún género) de Meza: La huella del conejo y La saga del conejo, editadas originalmente en volúmenes separados por El Equilibrista y reunidas en uno solo por el Fondo de Cultura Económica en 2007.

Julián sabe ser institucional, pero en otros terrenos es un espejo de incorrección política. No porque la cultive como pose, sino porque parece estar en su ADN, como puede advertirlo el lector de su obra y deben saberlo sin duda los asistentes a sus cursos. Indispuesto siempre a ver los trajes de los emperadores, Julián tuvo durante un tiempo una exclamación que lo distinguía: “¡Qué horror!”; una expresión que en estos días, donde el empleo profuso de signos de puntuación sustituye al abecedario, al léxico, a la sintaxis y aún a la semántica, merecería una guarnición abundante de dichos signos. Quede la tarea para sus alumnos, ciudadanos del feisbuc y tuiternautas, que lo habrán oído en más de una ocasión sintetizar sus juicios -o aún peor: calificar sus trabajos de clase-con un "¿Qué horror!".

Últimamente, a Julián le ha dado por buscar lugares remotos para sentarse a escribir-París, Sicilia o una isla del Egeo, por ejemplo-. No es talento menor saber encontrar el tiempo y los recursos necesarios para trasladarse a paisajes tan envidiables. De sus sesiones han resultado sobrios y breves libros de viaje (de nuevo por encajarlos dentro de algún género), como guijarros pulidos; una historia concisa de Sicilia, otra de Constantinopla; mucho más que ejercicios de descripción de algo tan inasible en pocas páginas. Pero no se crea que los años han mellado el filo crítico de Julián, o que su pluma se ha tornado para siempre dulce. Consúltese al respecto su Bestiario de historia mexicana, publicado en plena cruda de nuestros centenarios por El Equilibrista, en coedición con GM ediciones.

Termino asentando que expido este texto bajo amenaza de Julián de que, de no hacerlo, lo último que escucharé al ser excluido de su círculo íntimo será su célebre exclamación. 
CITAM Derechos Reservados.

La reproducción total o parcial de este artículo se podrá hacer si el ITAM otorga la autorización previamente por escrito.

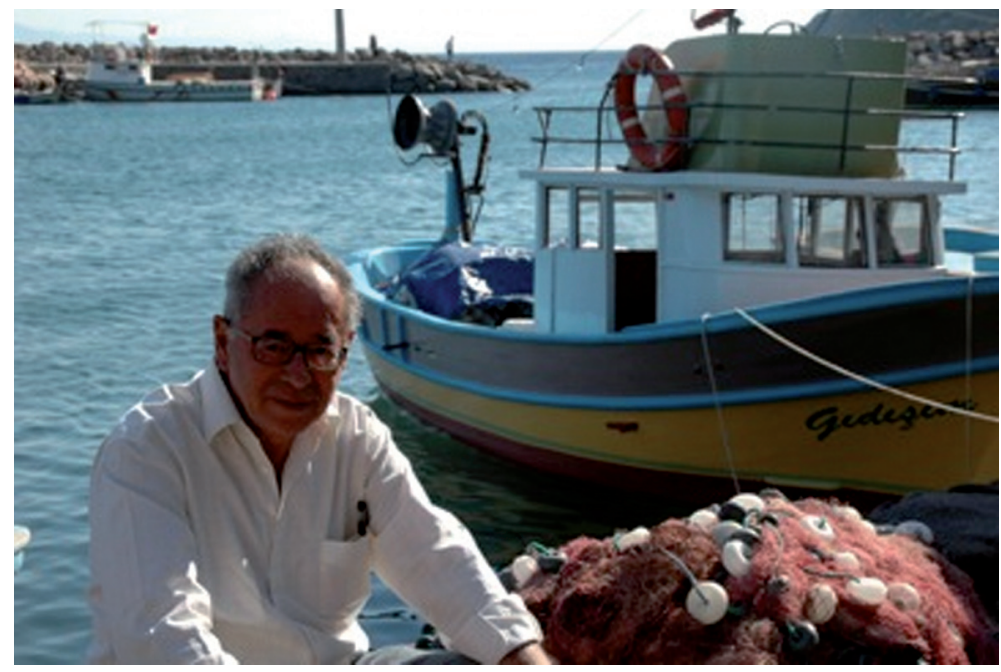

Puerto de Assos, Turquía. 